\title{
A STUDY ON THE FACTORS AFFECTING THE ACADEMIC PERFORMANCE OF DISTANCE EDUCATION STUDENTS AND FORMAL STUDENTS
}

\author{
Hakan $K O ̈ R^{l}$ \\ Hasan ERBAY2 \\ Emre DEMIR ${ }^{3}$ \\ Ömer Faruk AKMEŞE ${ }^{4}$
}

Citation/(-: Kör, Hakan; Erbay, Hasan, Demir, Emre; Akmeşe, Ömer Faruk (2016). A Study On The Factors Affecting The Academic Performance Of Distance Education Students And Formal Students, Hitit University Journal of Social Sciences Institute, Year 9, Issue 2, December 2016, pp. 1029-1050

Abstract: Recently the numbers of distance education programs and students enrolling in them have increased significantly. This increase also carries the question of what factors may have an effect on academic success. The demographic features, motivation levels, personal development status and basic computer literacy of students have been taken into account and their effects on the academic success of students have been analyzed. With this purpose, surveys prepared with the help of professional opinion have been applied to certain groups. The sample group of this study consists students of the Kirkkkale University Distance Education Center and the formal education students of the Kirkkale Vocational School. The results have been analyzed with the help of the SPSS data analysis program (version 22.0) and have been turned into figures. The academic success of distance learning students and formal education students have been compared and this data has been used to identify whether there are any significant connections between academic success and the factors determined. In the conclusion of this study, the figures have been explained separately, and suggestions have been made regarding both distance education and formal education.

Keywords: Distance Education; E-learning, Academic Success

Makale Geliş Tarihi: 12. 06. 2016/ Makale Kabul Tarihi: 22.07.2016

1 Öğr. Gör., Hitit Üniversitesi, Sungurlu Meslek Yüksek Okulu, e-posta: hakankor19@gmail.com

2 Prof. Dr., Ktrikkale Üniversitesi, Mühendislik Fakültesi, Bilgisayar Mühendisliği Bölümü, e-posta: hxe68@yahoo.com

3 Ögrr.Gör., Hitit Üniversitesi, Osmancık Ömer Derindere Meslek Yüksek Okulu, e-posta: emredemir82@gmail.com

4 Öğr. Gör., Hitit Üniversitei, Osmancık Ömer Derindere Meslek Yüksek Okulu, e-posta: o.faruk_akmese@hotmail.com. 


\section{Uzaktan ve Örgün Eğitim Öğrencilerinin Akademik Başarı Performanslarını Etkileyen Faktörlerin Araştırılması}

Atıf/O: Kör, Hakan; Erbay, Hasan, Demir, Emre; Akmeşe, Ömer Faruk (2016). Uzaktan ve Örgün Eğitim Öğrencilerinin Akademik Başarı Performanslarını Etkileyen Faktörlerin Araştırılması, Hitit Üniversitesi Sosyal Bilimler Enstitüsü Dergisi, Yıl 9, Sayı 2, Aralık 2016, ss. 1029-1050

Özet: Son zamanlarda, yüksek öğretim kurumlarında çok sayıda uzaktan eğitim programinın açıldığı ve kayıtlı öğrenci sayılarında ciddi artışlar olduğu gözlenmektedir. Uzaktan eğitimde öğrenci sayısındaki artışlar eğitimde başarıyı etkileyebilecek faktörlerin neler olabileceği sorusunu beraberinde getirmektedir. Bu çalışmada, uzaktan ve örgün eğitim öğrencilerinin demografik özellikleri, motivasyon seviyeleri, kişisel gelişim durumlar ve temel bilgisayar kullanım seviyelerinin akademik başarılarına olan etkisi araştırılmıştır. Bu amaçla, uzman görüşleri alınarak anket soruları hazırlanmış ve gruplara uygulanmıştır. Araştırmanin örneklemini, Kırıkkale Üniversitesi Uzaktan Eğitim Merkezinde eğitim alan öğrencilerle Meslek Yüksekokulun'da örgün olarak öğrenim gören öğrenciler oluşturmaktadır. Anket sorulan SPSS (versiyon 22.0) veri analiz paket programı ile analiz edilerek sonuçlar çizelgeler halinde verilmiştir. Uzaktan ve örgün eğitim alan öğrencilerin akademik başarılar ile araştırılan değişkenler arasında anlamlı bir farklılık olup olmadiğı tespit edilerek analiz kısmında verilmiştir. Çalışmanın sonuç bölümünde elde edilen çizelgeler yorumlanarak uzaktan ve örgün eğitim birimlerine, ayr ayr öneriler sunulmaktadır.

Anahtar Kelimeler: uzaktan eğitim, e-öğrenme, akademik başarı

\section{I.INTRODUCTION}

The rapid changes that have occurred in the field of information technologies have influenced distance education methods and techniques. The first distance learning method used was in the 18th century, with the help of letters sent by mail (İşman, 2011). However, nowadays, with the development of internet technologies, traditional teaching methods used in the classroom have been transferred to a virtual environment. In Turkey, as well as in many other universities or private and governmental institutions in the world, distance education is being used.

The rapid increase in information technologies and the simplicity of applying web-based education has put distance education in an important place in higher education (Koresdoski, 2000). In the United States, the number of ed- 
ucation programs that offer web-based solutions have increased by $73 \%$ from the 1994-5 academic year 1994-95 to the 1997-8 academic year (Soefijanto, 2002).

Individuals who were unable to continue their undergraduate, graduate or postgraduate education, for whatever reason, may now do so through distance learning. Therefore, distance learning offers equality of opportunity to individuals (Kör, 2013).

The facts that the number of universities offering distance education programs have increased, that the courses have become more varied and that the number of students applying to these programs is rising, raise the question of whether the given education is as efficient as it could be. That is why researchers are continuing to develop and improve online activities (Clark \& Kwinn, 2007; O’Neil, 2005, 2008; Reiser \& Dempsey, 2012).

\section{LITERATURE REVIEW}

The high school from which students graduate, their learning capabilities, their motivation for success, demographic features and their educational experience time-line are some of the useful factors when determining whether a student will be successful in face-to-face learning (Pachnowski and Jurczyk, 2000). These variable can be categorized to four: background (especially age and gender), preparedness (working skills, talents and analytical skills), self-respect and self-sufficiency, and motivation (Gibson, 1998). In distance and formal education, studies have been done on those individuals who have not yet graduated and those who have completed their undergraduate courses (Souder, 1994). When reviewing both educational methods, research has shown that in distance education, unlike in the traditional formal education method, there has been no significant connection between academic performance and gender, race or other demographic features. When looking at the age range of students, data has shown that students who are older had a tendency to do better in their classes in a distance education environment (Dille \& Mezack, 1991; Souder, 1994).

Many researchers have compared distance education and formal education from many different perspectives. In his doctorate thesis, Cadwell used a half-experimental design in a web-based "Introduction to Programming" class in order to identify the students' academic performance. In this study, vari- 
ables of academic performance, motivation, satisfaction and course completion rates were compared for three different teaching methods. These methods are 1) traditional face-to-face education, 2) web-based education, and 3) online education. The research showed that there was no significant connection between motivation or satisfaction and the three different teaching methods. However when looking at academic performance, the study has shown webbased education to be as effective as the traditional method (Cadwell, 2006). In another study that analyzed the effects of socializing and Facebook usage on academic success, it was revealed that using Facebook had a positive influence on academic performance (Ainin and others, 2015).

In her dissertation which compared learning strategies, Adile Aşkım Gülümbay revealed the connection between technological anxiety and academic success of students enrolled in web-based and traditional education programs. The study shows that there was no significant connection between the technological anxiety level of students enrolled in web-based programs and their corrected cognitive and metacognitive learning strategy average scores. Between the success rates of students enrolled in web-based programs or face-to-face programs, an advantage for face-to-face educational programs was identified. In other words, the final exam scores of students taking face-to-face courses were higher than those who were taking web-based courses (Gülümbay, 2009).

Carr analyzed whether there was a difference in success among students who have taken "Introduction to Psychology" classes in a web-based course or face-to-face course. This study revealed that students taking the web-based course had higher success rates (Carr, 2000). Schutte compared the success of students taking a social statistics course as a web-based course and as a face-to-face course. The research showed that students using web-based education had a $20 \%$ higher success rate than students using face-to-face education.

\section{III.METHOD}

In this part of the study, we will discuss the selection of sample groups, the conceptual model of the study, our hypothesis, the definition of the sample group, the data gathering process and analysis steps. 


\section{A. Sampling}

The sample group of this study consists of 106 students enrolled in the Computer Programming Program of Kirıkkale University's Vocational School, and 80 students from the Computer Programming Program of Kirikkale University's Distance Education Center.

\section{B. The Conceptual Model of the Study}

The main purpose of this study is to compare the factors affecting academic success of students enrolled in distance education and formal education programs. The factors claimed to have an effect on academic success are as follows: The demographic structure of the students, their personal development level, and their basic computer literacy skills. In order to illustrate the connection between academic success in the two different teaching methods and the given factors, a research model has been produced (Figure 1), as well as research hypotheses.

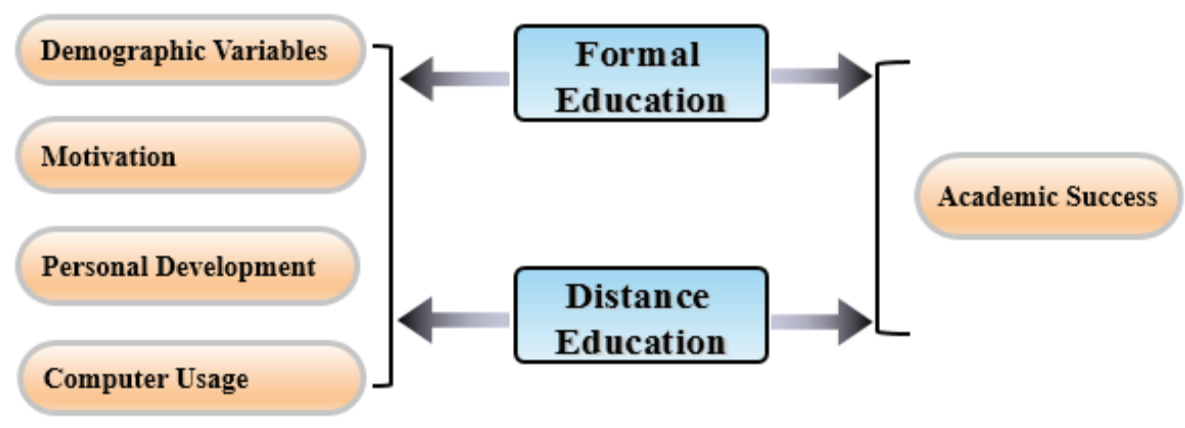

Figure 1. The Conceptual Model of the Study

\section{Research Hypotheses}

The 4 hypotheses, which we will use as criteria in this study, will be tested separately for both groups, distance education and formal education. The 5 th hypothesis will be tested for both groups, distance education learners and formal education learners. Based on the data gathered, generalizations are made on Turkish universities offering distance education and formal education programs in their higher education institutes.

H1: The academic success of students shows a significant relationship to their demographics (H1.1.gender, H1.2.age, H1.3.place of residence, H1.4.high school education, H1.5.employment status, H1.6.family income, H1.7.place of accommodation). 
H2: There is a significant relationship between the students' motivation levels and their academic success.

H3: The personal development level of the students and the type of education they are receiving is significantly related to their academic success.

H4: The students' skills in using operating systems and office programs and the type of education they are receiving is significantly related to their academic success.

H5: The students' motivation, their personal development level and their basic computer literacy skills changes according to the type of education (distance education or formal education) they are receiving.

\section{Data Collection Tool: Preparation and Implementation of the survey}

A survey has been used as the data collection tool of this study. At the first stage of the study, a survey with questions split in different categories has been implemented. The survey was distributed to students through the internet. The prepared survey was uploaded on the web site of the university and was opened to access under the web address: www.sungurlumyo.hitit. edu.tr/ders/distanceeducationsurvey (Kor, 2013).

The survey has been distributed to students who have the same curriculum presented to them with different teaching methods. Therefore it has been predetermined from which perspectives the two education methods (distance education and formal education) should be compared in order to realize which factors are significant for the study. During the preparation of the survey the opinions of professors who are experts in the field of educational science have been taken into account and questions and answer options have been prepared in accordance with survey rules. Five-point Likert-type questions have been used in the survey and the questions have been categorized according to the knowledge that the researchers hoped to acquire.

Among the students who participated in the survey, 186 of them have been included in the analysis, as other surveys were not fully complete. The SPSS (version 22.0) package program has been used for the analysis.

\section{E. Reliability and Factor Analysis}

At this part of the study a reliability and factor analysis has been applied to the data stored in the database. The most common method to identify the reliability is the Cronbach alpha (a) coefficient and this rate is generally preferred to be higher than 0.70 . 
The Cronbach Alpha reliability analysis has been used to rate the reliability of the data. The reliability scale was calculated to be 0.822 . Accordingly, it has been determined that the survey is $82.2 \%$ reliable. The reliability coefficient which would be acquired when scale items were deleted was also calculated. After analyzing the results, it has been determined that out of 42 questions some had a low reliability score and therefore the questions were reduced to 25 questions. Out of the remaining 25 questions, 18 that didn't include demographic variables were subjected to a factor analysis, and the results of this has been given in Table 1 .

\section{Reliability Analysis}

Table 1. The Results of the Reliability Analysis

\begin{tabular}{|c|c|}
\hline \multicolumn{2}{|c|}{ Reliability Statistics } \\
\hline Cronbach's Alpha & N of Items \\
\hline 0.822 & 25 \\
\hline
\end{tabular}

When examining Table 1, we can see that the survey has scored a relatively high result according to Cronbach's Alpha coefficient, which is a 0.822 .

\section{Factor Analysis}

Out of the 18 questions which were within the distance education scale, a factor analysis has been applied to reduce the survey size. According to the rotated component matrix, 1 question was not in accordance with the factor analysis and was thus removed. After the second factor analysis, another question gathered under one factor was removed. Finally, after the last factor analysis, 16 questions were gathered under 3 factors.

Table 2. Factor Analysis Test Results

\begin{tabular}{|c|c|c|}
\hline \multicolumn{2}{|c|}{$\begin{array}{c}\text { Kaiser-Meyer-Olkin Measure of Sampling } \\
\text { Adequacy }\end{array}$} & 0.872 \\
\hline \multirow{2}{*}{$\begin{array}{c}\text { Bartlett's Test of } \\
\text { Sphericity }\end{array}$} & Chi-square Statistic & 1189.448 \\
\cline { 2 - 3 } & $\mathrm{sd}$ & 120 \\
\cline { 2 - 3 } & $\mathrm{p}$ & 0.001 \\
\hline
\end{tabular}

Related to the answers given for the distance education scale, the results are being shown in accordance with the Barlett Sphericity Test and KMO sample qualification results. The results of the Barlett Sphericity tests show that there are meaningful correlations between the variables $(\mathrm{p}<0.05)$. According to the KMO statistics, the survey is approximately $87.2 \%$ in accordance with the factor analysis. 
Table 3. Factor Analysis Test Values

\begin{tabular}{|c|c|c|c|c|}
\hline \multirow{2}{*}{ Component } & \multirow{2}{*}{ Eigenvalues } & \multicolumn{3}{|c|}{ Extraction Sums of Squared Loadings } \\
\hline & Total & Total & Variance \% & Cumulative \% \\
\hline 1 & 5.485 & 4.224 & 26.403 & 26.403 \\
\hline 2 & 2.580 & 2.530 & 15.813 & 42.215 \\
\hline 3 & 1.155 & 2.466 & 15.414 & 57.630 \\
\hline
\end{tabular}

When examining Table 3, it has been identified that there are 3 factors whose eigenvalues are higher than 1 . Factors with eigenvalues smaller than 1 are not shown on the table. The obtained factor explains a total $57.63 \%$ of the variables.

Table 4. Factor Analysis Item Loads

\section{Item}

Questions (abbreviated)

Q8 : Assessment and content is appropriate.

Q6 : The content serves for the purpose.

Q9 : Formal assessment is appropriate.

Q7 : Materials are used.

Q4 : Content is appropriate for the level.

Q5 : The content is updated.

Q1 : The content is appropriate for the level of readiness.

Q3 : I will get a good job.

Q10: Distance assessment is appropriate.

Q16 : Levels about the usage of Spreadsheet Program.

Q17 : Levels about the usage of Presentation Program.

Q15 : Levels about the usage of Word

Processing Program.

Q18 : Levels about the usage of Database

Program.

\section{Factor}

2 3

Q11 : Lifelong learning. 
On Table 4, the rotated component matrix of all questions are shown. On this matrix we can see which question falls under which factor. The correlation values between each question and the factor are also illustrated. According to the factor analysis results the 3 factors have been named thusly:

Table 5. Factor Names

\begin{tabular}{|c|l|}
\hline Factors & \multicolumn{1}{|c|}{ Factor Names } \\
\hline 1. Factor & Motivation \\
\hline 2. Factor & Basic Computer Usage \\
\hline 3.Factor & Personel Development \\
\hline
\end{tabular}

\section{F. Demographic Characteristics}

This part of the study informs about the students' gender, age, place of residence, family income, accommodation unit, employment status and the type of high school they have graduated from. The demographic characteristics of the students have been given on Figure 2 and Figure 3.
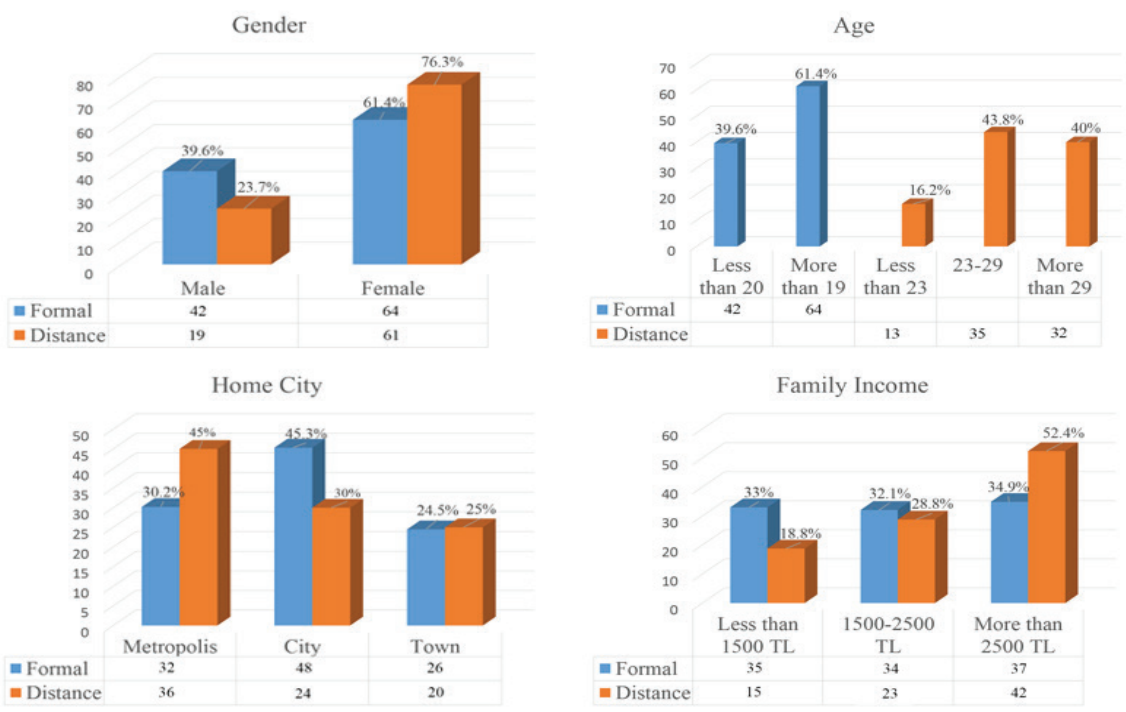

Figure 2. Demographical Characteristics of the Students

In Figure 2, we can see that according to the gender distribution, there are 1.5 times more females than males in the formal education group, whereas there are 3 times more female students than males in the distance education group. When looking at the age distribution of the students, it can be seen 
that $39.6 \%$ of the students in formal education are younger than 20 , whereas in the distance education group only $16.2 \%$ of the students are younger than 23. When looking at the home city of the students, we can see that $45.3 \%$ of the students in formal education live in the city, whereas $45 \%$ of the distance education students live in a metropolitan area. When looking at the students' family income rates, we see that in the formal education group 33\% of the students' families have a monthly income lower than $1500 \mathrm{TL}$, and 34.9\% of the students' families have a monthly income higher than 2500 TL. In the distance education group, $18.8 \%$ of the students' families' monthly income is lower than $1500 \mathrm{TL}$, whereas $52.4 \%$ of the students' families' monthly income is higher than 2500 TL.
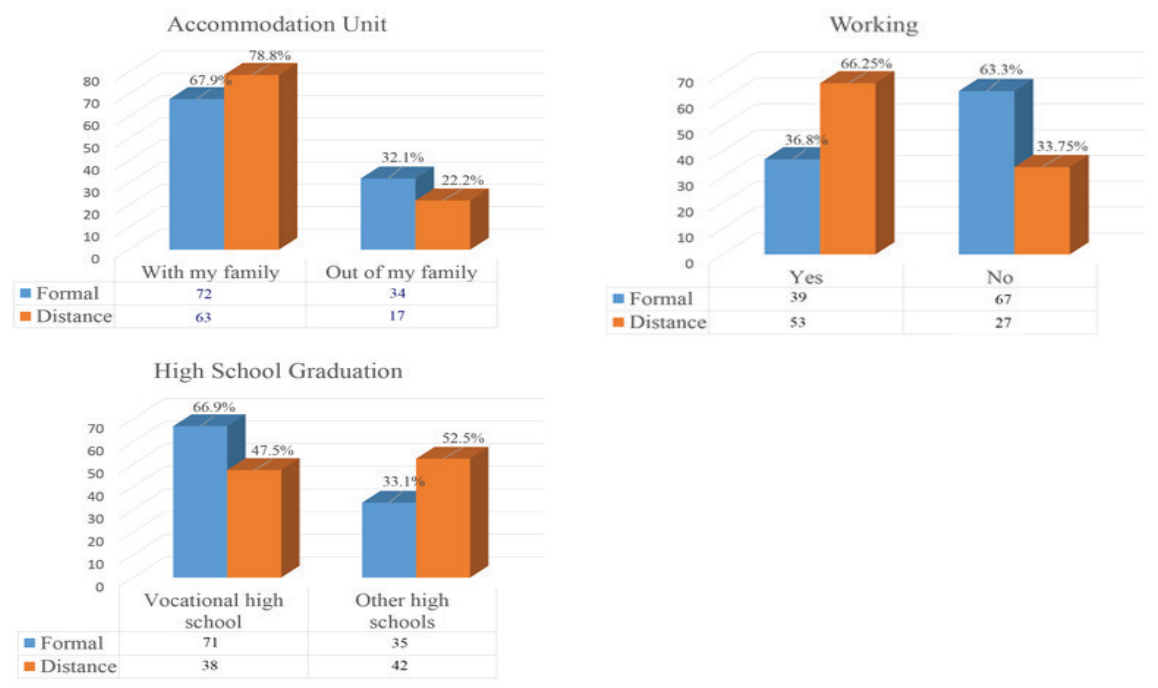

Figure 3. Demographic Characteristics (continued)

In Figure 3, when looking at the students' accommodation units, we see that $78.8 \%$ of the students of the distance education group are living with their families, whereas this rate is $67.9 \%$ for the students in the formal education group. Looking at the students' employment status, we see that among the formal education group $36.8 \%$ work in a job with a salary, whereas $66.25 \%$ of this group is not employed. When looking at the distribution of the types of high schools the students have graduated from, we see that $66.9 \%$ of the formal education group has graduated from vocational high schools, whereas $33.1 \%$ of the distance education groups has graduated from vocational high schools. 


\section{RESULTS}

In this part of the study, hypotheses on which factors affect the students' academic performance have been tested. The normality assumption in statistical analyses has been tested with the Kolmogorov-Smirnov test. The two-average comparisons were done with the independent sample $t$ and the Mann Whitney $\mathrm{U}$ test. In multiple comparisons the homogeneity of the variables were examined through the Levene Test and the Analysis of Variance (ANOVA) test was used in comparisons. In cases when the sample numbers are not equal in the compared groups, the Tukey test is not usable, because Tukey posits that groups should have an equal number of samples (Tukey, 1949). The Scheffe method was developed in order to compare all possible linear combinations amongst groups. This method is considered to be a post-hoc type that does not take into consideration whether groups are equally numbered or not. This method is flexible and can control the tolerance of a (conservative) in cases where there are many groups being compared (Scheffe, 1953; Scheffe, 1959). In the study, as the sample group numbers were not equal, in order to cite the source of the meaningful differences appearing in the data, we have used ANOVA and then among post-hoc tests the Scheffe and Bonferroni tests. The main idea of the study is to discuss the theoretical dimensions of the differences between these groups.

\section{Hypothesis 1.1 Test Results}

Table 6. The Comparison of the Students' Success Scores According to Their Gender with the t Test

\begin{tabular}{|c|c|c|c|c|c|c|c|}
\hline \multirow{2}{*}{ Groups } & \multirow{2}{*}{ Gender } & \multirow[b]{2}{*}{$N$} & \multirow{2}{*}{ Mean } & \multirow{2}{*}{$\begin{array}{c}\text { Std. } \\
\text { Deviation }\end{array}$} & \multirow[b]{2}{*}{ Std.Error } & \multicolumn{2}{|c|}{$t$ Test } \\
\hline & & & & & & $\begin{array}{c}\text { Mean } \\
\text { Difference }\end{array}$ & $p$ \\
\hline \multirow{2}{*}{ Formal } & Male & 42 & 1.827 & 0.597 & 0.074 & \multirow{2}{*}{-0.529} & \multirow{2}{*}{0.002} \\
\hline & Female & 64 & 2.356 & 0.509 & 0.078 & & \\
\hline \multirow{2}{*}{ Distance } & Male & 19 & 2.508 & 0.408 & 0.052 & \multirow{2}{*}{0.198} & \multirow{2}{*}{0.082} \\
\hline & Female & 61 & 2.310 & 0.486 & 0.111 & & \\
\hline
\end{tabular}

When examining the table, we see a difference between the success rate of students according to gender $(p=0.002<0.05)$. In formal education we see that females are generally more successful than males. In distance education their academic performances show no significant difference $(p=0.082>0.05)$. 
Hypothesis 1.2 Test Results

Table 7. The Comparison of the Students' Success Scores According to Their Age with the t Test (Formal Education)

\begin{tabular}{|l|l|c|c|c|c|c|c|}
\hline Groups & Age & $N$ & Mean & $\begin{array}{c}\text { Std. } \\
\text { Deviation }\end{array}$ & Std.Error & $\begin{array}{r}\text { Mean } \\
\text { Mest } \\
\text { Difference }\end{array}$ & $p$ \\
\hline Formal & $\begin{array}{l}\text { Less } \\
\text { than } \\
20\end{array}$ & 42 & 1.9540 & 0.55728 & 0.08599 & & \\
\cline { 2 - 6 } \\
$\begin{array}{l}20 \\
\text { and } \\
\text { More } \\
\text { than } \\
20\end{array}$ & 64 & 2.0911 & 0.65526 & 0.08191 & & \\
\hline
\end{tabular}

When examining Table 7 we see that there is no significant difference between the students' ages and their academic performances $(p=0.267>0.05)$.

Table 8. The Comparison of the Students' Success Scores According to Their Age with the ANOVA Test (Distance Education)

\begin{tabular}{|c|c|c|c|c|c|c|c|}
\hline Groups & Age & $\mathrm{N}$ & Mean & $\begin{array}{c}\text { Std. } \\
\text { Deviation }\end{array}$ & & $\begin{array}{c}\text { Std.Error } \\
\text { Levene Statistic } \\
\text { (Test of } \\
\text { Variances) }\end{array}$ & $p$ \\
\hline \multirow{5}{*}{ Distance } & $\begin{array}{l}\text { Less } \\
\text { than } \\
23\end{array}$ & 13 & 2.2954 & 0.54901 & & & \\
\cline { 2 - 6 } & $23-29$ & 35 & 2.4331 & 0.41914 & 0.07085 & 0.062 & \multirow{2}{*}{0.157} \\
\cline { 2 - 6 } & $\begin{array}{l}\text { More } \\
\text { than } \\
29\end{array}$ & 32 & 2.5600 & 0.38418 & & & \\
\hline
\end{tabular}

When examining the table we see that there is no significant difference between the students' ages and their academic performances $(p=0.157>0.05)$. 
A Study on The Factors Affecting The Academic Performance of Distance Education Students And Formal Students

Hypothesis 1.3 Test Results

Table 9. The Comparison of the Students' Success Scores According to Their Home Town with the ANOVA Test

\begin{tabular}{|c|l|c|c|c|c|c|c|}
\hline Groups & Home City & $\mathrm{N}$ & Mean & $\begin{array}{c}\text { Std. } \\
\text { Deviation }\end{array}$ & Std. Error & $\begin{array}{c}\text { Levene Statistic } \\
\text { (Test of } \\
\text { homogeity of } \\
\text { Variances) }\end{array}$ & $p$ \\
\hline \multirow{4}{*}{ Formal } & Metropolis & 32 & 1.8143 & 0.51506 & 0.09404 & \multirow{2}{*}{0.282} & \multirow{2}{*}{0.058} \\
\cline { 2 - 6 } & City & 48 & 2.1083 & 0.63689 & 0.08024 & & \\
\cline { 2 - 6 } & Town & 26 & 2.2038 & 0.66128 & 0.18341 & & \multirow{2}{*}{0.0157} \\
\hline \multirow{3}{*}{ Distance } & Metropolis & 36 & 2.5402 & 0.39198 & 0.05060 & & \\
\cline { 2 - 6 } & City & 24 & 2.2840 & 0.39215 & 0.12401 & & \\
\cline { 2 - 5 } & Town & 20 & 2.1670 & 0.56370 & 0.17826 & & \\
\hline
\end{tabular}

When examining the table we see that there is no significant difference between formal education performances according to where students live $(p=0.058>0.05)$. However a difference has been spotted in distance education performances according to where students live $(\mathrm{p}=0.014<0.05)$.

Table 10. Post-hoc (Scheffe-Bonferroni) Test Results Made to Identify How Success Rates Changes According to Different Groups for Distance Education Students

\begin{tabular}{|c|c|c|c|c|c|}
\hline & Home City & Home City & $\begin{array}{c}\text { Mean } \\
\text { Difference }\end{array}$ & $\begin{array}{l}\text { Std. } \\
\text { Error }\end{array}$ & Sig. \\
\hline \multirow{6}{*}{ Scheffe } & \multirow{2}{*}{ Metropolis } & City & 0.25617 & 0.14200 & 0.203 \\
\hline & & Town & $0.37317^{*}$ & 0.14200 & 0.037 \\
\hline & \multirow{2}{*}{ City } & Metropolis & -0.25617 & 0.14200 & 0.203 \\
\hline & & Town & 0.11700 & 0.18593 & 0.821 \\
\hline & \multirow{2}{*}{ Town } & Metropolis & $-0.37317^{*}$ & 0.14200 & 0.037 \\
\hline & & City & -0.11700 & 0.18593 & 0.821 \\
\hline \multirow{6}{*}{ Bonferroni } & \multirow{2}{*}{ Metropolis } & City & 0.25617 & 0.14200 & 0.225 \\
\hline & & Town & $0.37317^{*}$ & 0.14200 & 0.031 \\
\hline & \multirow{2}{*}{ City } & Metropolis & -0.25617 & 0.14200 & 0.225 \\
\hline & & Town & 0.11700 & 0.18593 & 0.000 \\
\hline & \multirow{2}{*}{ Town } & Metropolis & $-0.37317^{*}$ & 0.14200 & 0.031 \\
\hline & & City & -0.11700 & 0.18593 & 0.932 \\
\hline
\end{tabular}

* Mean difference is significant with post-hoc test $(\mathrm{p}<0.05)$. 
When examining the table we see a meaningful difference between the performances of students living in towns and metropolitan areas. (Scheffe $p=0.037<0.05$, Bonferroni $p=0.031<0.05$ ). It can be clearly seen from Table 9 that students living in metropolitan areas have higher scores than those living in cities, and that those living in cities have higher scores than students who live in towns.

\section{Hypothesis 1.4 Test Results}

Table 11. The Comparison of the Students' Success Scores According to The Type of High Scool They Graduated From with the t Test

\begin{tabular}{|c|c|c|c|c|c|c|c|}
\hline Groups & Groups & $N$ & Mean & $\begin{array}{c}\text { Std. } \\
\text { Deviation }\end{array}$ & Std.Error & $\begin{array}{c}\quad t \text { Te } \\
\text { Mean } \\
\text { Difference }\end{array}$ & $p$ \\
\hline \multirow{2}{*}{ Formal } & $\begin{array}{l}\text { Vocational } \\
\text { High School }\end{array}$ & 71 & 1.96 & 0.61617 & 0.06459 & \multirow{2}{*}{-0.53878} & \multirow{2}{*}{0.001} \\
\hline & $\begin{array}{l}\text { Other High } \\
\text { School }\end{array}$ & 35 & 2.49 & 0.40983 & 0.10582 & & \\
\hline \multirow{2}{*}{ Distance } & $\begin{array}{l}\text { Vocational } \\
\text { High School }\end{array}$ & 38 & 2.45 & 0.42361 & 0.06872 & \multirow{2}{*}{-0.01940} & \multirow{2}{*}{0.843} \\
\hline & $\begin{array}{l}\text { Other High } \\
\text { School }\end{array}$ & 42 & 2.47 & 0.44764 & 0.06907 & & \\
\hline
\end{tabular}

When looking at the table we see a statistical difference in the performance of formal education students based on the type of high school from which they graduated $(\mathrm{p}=0.001<0.05)$. The academic performance of vocational high school graduates in formal education was lower compared to other types of high schools. However a significant difference has not been spotted in distance education $(\mathrm{p}=0.843>0.05)$. 
A Study on The Factors Affecting The Academic Performance of Distance Education Students And Formal Students

Hypothesis 1.5 Test Results

Table 12. The Comparison of the Students' Success Scores According to Their Employment Status with the t Test

\begin{tabular}{|c|c|c|c|c|c|c|c|}
\hline Groups & Working & $N$ & Mean & $\begin{array}{c}\text { Std. } \\
\text { Deviation }\end{array}$ & $\begin{array}{l}\text { Std. } \\
\text { Error }\end{array}$ & $\begin{array}{c}t \mathrm{Te} \\
\text { Mean } \\
\text { Difference }\end{array}$ & $p$ \\
\hline \multirow{2}{*}{ Formal } & Yes & 39 & 1.95 & 0.57468 & 0.13184 & \multirow{2}{*}{-0.10126} & \multirow{2}{*}{0.521} \\
\hline & No & 67 & 2.05 & 0.63020 & 0.06756 & & \\
\hline \multirow{2}{*}{ Distance } & Yes & 53 & 2.49 & 0.44971 & 0.05666 & \multirow{2}{*}{0.17147} & \multirow{2}{*}{0.149} \\
\hline & No & 27 & 2.32 & 0.34731 & 0.08424 & & \\
\hline
\end{tabular}

When examining the tables we see no statistically significant difference between academic performance and employment status, for neither formal education students nor for distance education students $(\mathrm{p}=0.521>0.05$ and $\mathrm{p}=0.149>0.05$, respectively).

\section{Hypothesis 1.6 Test Results}

Table 13. The Comparison of the Students' Success Scores According to Their Families' Income with the ANOVA Test

\begin{tabular}{|c|c|c|c|c|c|c|c|}
\hline Groups & Home City & $\mathrm{N}$ & Mean & $\begin{array}{c}\text { Std. } \\
\text { Deviation }\end{array}$ & Std.Error & $\begin{array}{c}\text { Levene } \\
\text { Statistic } \\
\text { (Test of } \\
\text { homogeneity } \\
\text { of Variances) }\end{array}$ & $p$ \\
\hline \multirow{3}{*}{ Formal } & $\begin{array}{l}\text { Less than } \\
1500\end{array}$ & 35 & 2.1640 & 0.58558 & 0.09898 & \multirow{3}{*}{0.325} & \multirow{3}{*}{0.328} \\
\hline & $1500-2500$ & 34 & 1.9903 & 0.65483 & 0.11230 & & \\
\hline & $\begin{array}{l}\text { More than } \\
2500\end{array}$ & 37 & 1.9592 & 0.61435 & 0.10100 & & \\
\hline \multirow{3}{*}{ Distance } & $\begin{array}{l}\text { Less than } \\
1500\end{array}$ & 15 & 2.3460 & 0.44985 & 0.11615 & \multirow{3}{*}{0.454} & \multirow{3}{*}{0.076} \\
\hline & $1500-2500$ & 23 & 2.3465 & 0.45423 & 0.09471 & & \\
\hline & $\begin{array}{l}\text { More than } \\
2500\end{array}$ & 42 & 2.5657 & 0.39909 & 0.06158 & & \\
\hline
\end{tabular}


When examining the tables we see that there is no significant connection between academic performance and families' incomes for formal education or in distance education students $(\mathrm{p}=0.328>0.05$ and $\mathrm{p}=0.076>0.05$, respectively).

Hypothesis 1.7 Test Results

Table 14. The Comparison of the Students' Success Scores According to Their Accommodation Unit with the Mann Whitney-U Test

\begin{tabular}{|c|c|c|c|c|c|c|c|c|}
\hline Groups & Gruplar & $N$ & Mean & $\begin{array}{c}\text { Std. } \\
\text { Deviation }\end{array}$ & $\begin{array}{l}\text { Mean } \\
\text { Rank }\end{array}$ & $\begin{array}{l}\text { Sum of } \\
\text { Ranks }\end{array}$ & $U$ & $p$ \\
\hline & $\begin{array}{l}\text { With my } \\
\text { family }\end{array}$ & 72 & 2.05 & 0.68295 & 55.09 & 3966.50 & & \\
\hline Formal & $\begin{array}{l}\text { Outside } \\
\text { the } \\
\text { family }\end{array}$ & 34 & 2.00 & 0.46340 & 50.13 & 1704.50 & 1109.500 & 0.438 \\
\hline \multirow[b]{2}{*}{ Distance } & $\begin{array}{l}\text { With my } \\
\text { family }\end{array}$ & 63 & 2.48 & 0.43815 & 41.63 & 2622.50 & \multirow[b]{2}{*}{464.500} & \multirow[b]{2}{*}{0.404} \\
\hline & $\begin{array}{l}\text { Outside } \\
\text { the } \\
\text { family }\end{array}$ & 17 & 2.38 & 0.42094 & 36.32 & 617.50 & & \\
\hline
\end{tabular}

Since the data is not normally distributed the average comparisons were made with the non-parametric equivalent of the sample t test, which is the Mann Whitney Rank test. When examining the table we see that there is no significant connection between accommodation units and academic performance for formal education or distance education students $(p=0,438>0.05$ ve $p=0.404>0.05)$.

\section{Hypothesis 2 Test Results}

Table 15. The Comparison of the Students' Success Scores According to Motivation Levels with the ANOVA Test

\begin{tabular}{|c|c|c|c|c|c|c|}
\hline \multirow{2}{*}{ Groups } & Motivation & $N$ & Mean & $\begin{array}{c}\text { Std. } \\
\text { Deviation }\end{array}$ & $\begin{array}{c}\text { Levene Statistic } \\
\text { (Test of } \\
\text { homogeneity of } \\
\text { Variances) }\end{array}$ & $p$ \\
\hline \multirow{3}{*}{ Formal } & $1-15$ & 21 & 2.0938 & 0.58165 & \multirow{2}{*}{0.239} & \multirow{2}{*}{0.272} \\
\cline { 2 - 5 } & $16-30$ & 55 & 1.9458 & 0.68436 & \\
\cline { 2 - 5 } & $31-45$ & 30 & 2.1637 & 0.49813 & \multirow{2}{*}{0.955} \\
\cline { 2 - 5 } Distance & $1-15$ & 28 & 2.4746 & 0.46895 & \\
\cline { 2 - 5 } & $16-30$ & 33 & 2.4436 & 0.45324 & & \\
\cline { 2 - 5 } & $31-45$ & 19 & 2.4732 & 0.36003 & & \\
\hline
\end{tabular}


A Study on The Factors Affecting The Academic Performance of Distance Education Students And Formal Students

When examining the table we see no significant difference in the performances of distance education or formal education students according to motivation levels $(\mathrm{p}=0.272>0.05$ and $\mathrm{p}=0.955>0.05$, respectively).

\section{Hypothesis 3 Test Results}

Table 16. The Comparison of the Students' Success Scores According to Personal Development Levels with the ANOVA Test

\begin{tabular}{|c|c|c|c|c|c|c|}
\hline \multirow{7}{*}{ Groups } & $\begin{array}{c}\text { Personnel } \\
\text { Development }\end{array}$ & $N$ & Mean & $\begin{array}{c}\text { Std. } \\
\text { Deviation }\end{array}$ & $\begin{array}{c}\text { Levene Statistic } \\
\text { (Test of } \\
\text { homogeneity of } \\
\text { Variances) }\end{array}$ & $p$ \\
\hline \multirow{3}{*}{ Formal } & $1-5$ & 12 & 1.8158 & 0.45000 & \multirow{2}{*}{0.340} & \multirow{2}{*}{0.262} \\
\cline { 2 - 5 } & $6-10$ & 60 & 2.1123 & 0.65419 & \multirow{2}{*}{0.891} \\
\cline { 2 - 5 } Distance & $11-15$ & 34 & 1.9815 & 0.59669 & \\
\cline { 2 - 5 } & $1-5$ & 19 & 2.4216 & 0.54680 & & \\
\cline { 2 - 5 } & $11-15$ & 26 & 2.4638 & 0.44631 & & \\
\hline
\end{tabular}

When examining the table we see that there is no significant connection between academic performance and the students' personal development levels, for formal education or distance education students $(\mathrm{p}=0.262>0.05$ and $\mathrm{p}=0.891>0.05$ respectively).

\section{Hypothesis 4 Test Results}

Table 17. The Comparison of the Students' Success Scores According to Computer Literacy Levels with the ANOVA Test

\begin{tabular}{|c|c|c|c|c|c|c|}
\hline \multirow{2}{*}{ Groups } & Computer & $N$ & Mean & $\begin{array}{c}\text { Std. } \\
\text { Deviation }\end{array}$ & $\begin{array}{c}\text { Levene Statistic } \\
\text { (Test of } \\
\text { homogeneity of } \\
\text { Variances) }\end{array}$ & $p$ \\
\hline \multirow{3}{*}{ Formal } & $1-6$ & 18 & 2.0963 & 0.90516 & & \multirow{2}{*}{0.701} \\
& $7-13$ & 22 & 2.1250 & 0.54989 & 0.058 & \multirow{2}{*}{0.207} \\
\cline { 2 - 5 } & $14-20$ & 66 & 2.0050 & 0.60989 & & \\
\cline { 2 - 5 } & $1-6$ & 14 & 2.3993 & 0.43050 & & \\
\hline
\end{tabular}


When examining the table we see that there is no significant connection between academic performance and the students' computer literacy levels, for formal education or distance education students $(p=0.701>0.05$ and $\mathrm{p}=0.207>0.05$, respectively).

\section{Hypothesis 5 Test Results}

Table 18. The Comparison Motivation, Personal Development Levels and Computer Literacy Within the Variable Groups with the T Test

\begin{tabular}{|c|c|c|c|c|c|c|c|}
\hline & Groups & $N$ & Mean & $\begin{array}{c}\text { Std. } \\
\text { Deviation }\end{array}$ & Std.Error & $\begin{array}{c}t \text { Te } \\
\text { Mean } \\
\text { Difference }\end{array}$ & $p$ \\
\hline \multirow{2}{*}{ Motivation } & Formal & 106 & 31.4245 & 6.56099 & 0.63726 & \multirow{2}{*}{2.53703} & \multirow{2}{*}{0.001} \\
\hline & Distance & 80 & 28.8875 & 8.80304 & 0.98421 & & \\
\hline \multirow{2}{*}{$\begin{array}{l}\text { Personnel } \\
\text { Development }\end{array}$} & Formal & 106 & 10.2736 & 2.18450 & 0.21218 & \multirow{2}{*}{0.74858} & \multirow{2}{*}{0.032} \\
\hline & Distance & 80 & 9.5250 & 3.16618 & 0.35399 & & \\
\hline \multirow{2}{*}{$\begin{array}{l}\text { Computer } \\
\text { Usage }\end{array}$} & Formal & 106 & 19.8679 & 4.69260 & 0.45579 & \multirow{2}{*}{2.45542} & \multirow{2}{*}{0.072} \\
\hline & Distance & 80 & 17.4125 & 5.17955 & 0.57909 & & \\
\hline
\end{tabular}

In Table 18 it can be seen that within distance education and formal education student groups the variables of motivation, personal development levels and computer literacy levels have been compared with the independent sample $t$ test. No significant statistical connection can be seen between the groups based on the variable of personal development levels $(p=0.072>0.05)$. However a significant connection can be seen within the groups when comparing motivation scores $(p=0.032<0.05)$. It can clearly be seen that motivation scores of distance education students are significantly lower than formal education students. Further, when examining the computer literacy levels of the students, we can also see a significant connection $(p=0.001<0.05)$. It can be seen from the table that distance education students have lower computer literacy levels than formal education students.

\section{CONCLUSION AND DISCUSSION}

At this part of the study, we are assessing the demographic characteristics of the distance education and formal education students, the hypothesis test results and the results of the tests comparing between groups. When 
examining the demographic characteristics, we see that formal education and distance education students primarily consist of females. In the formal education group there was a significant connection between academic success and gender. Looking at the final grades of the students, we see that female students are more successful at school than their male counterparts.

Looking at the graphics reflecting the students' age groups we see that in the formal education group there are more students under the age of 20, compared to the distance education group. In the distance education group we see there are significantly more students older than the age of 23 than the formal education group. Therefore the distance education group has far more students above the average age group for university students. However we can say that this age difference does not significantly contribute to academic performance.

In the distance education group, we see that most students are living in metropolitan areas or cities, that they are more likely to be employed in a job and that they are likely to have a higher income. Students living in metropolitan areas have an easier time finding jobs and thus have a higher income range than formal education students. In other words, it can be said that most distance education students' work and study at the same time.

In the table showing whether there is a significant connection between accommodation units and academic success, we have seen a difference between students living in metropolitan areas and students living in towns for the distance education group. We see that students living in metropolitan areas have a relatively higher final score than students living in towns. It can be argued that this is because students living in metropolitan areas have easier access to computer equipment and internet technologies.

Most of the formal education students consist of vocational high school graduates. In this case it can be argued that most of these students have been put into an undergraduate program without an examination. On the other hand, in the distance education group there is almost a 50:50 ratio of students graduated from vocational high schools and from other high schools. In the formal education group the majority have graduated from vocational high schools and thus their academic success rate is significantly lower than the distance education group. It can be argued that the reason of this is that generally students with low academic success prefer to enroll in vocational high schools. Accordingly, it can be suggested that the Ministry of Education should review and revise their vocational high school curricula. 
Looking at the accommodation units of the students, we see that there is no real significance between two groups, although we can say that formal education students are slightly more likely to live with their families.

$\mathrm{H} 2, \mathrm{H} 3, \mathrm{H} 4$ hypotheses that are claiming to have successful results on undergraduate students motivation, personal development and academic success are rejected for undergraduate students both studying from a distance and in formal education. When $\mathrm{H} 2, \mathrm{H} 3$ and $\mathrm{H} 4$ hypotheses are analyzed between groups, a meaningful difference in motivation and personal development score levels between them and H5 are detected. Even though the academic success average of the distance education group is higher than the formal education group, the latter has higher levels of motivation and computer literacy as a surprising result.

The information gathered in the finality was given to the Kırıkkale University Distance Education and Vocational School (Formal) departments as a proposal.

\section{A. Limitations and Future Research}

This research is limited to distance and formal undergraduate students that are studying in Kirikkale University Distance Education and Vocational School. In the future we plan to execute a survey with different universities and a more extensive populace to further this research.

\section{REFERENCES}

AININ, S. (2015) Facebook usage, socialization and academic performance, Computer $\&$ Education, 83(1), 64-73.

CALDWELL, E.R. (2006). A comparative study of three instructional modalities in a computer-programming course: traditionalinstruction, web based instruction, and online instruction. Unpublished PDH Thesis. USA: The University of North Carolina at Greensboro.

CLARK, R. C., \& Kwinn, A. (2007). The new virtual classroom. San Francisco: Pfeiffer.

CARR, S. (2000) Online psychology instruction is effective, but not satisfying, study finds. Chronicle of Higher Education, 46(27), pA48, 2/5p. Retrieved April 6, 2014 online from Academic Search Elite database.

DILLE, B., \& Mezack, M. (1991). Identifying predictors of high risk among community college telecourse students. The American Journal of Distance Education, 5(1), 24-35. 
GIBSON, C. C. (1998). The distance learner's academic self-concept. In C.C. GIBSON (Ed.) Distance Learners in Higher Education: Institutional responses for quality outcomes (p. 65-76). Madison, WI.: Atwood.

GÜLÜMBAY, A. A. (2005). Yükseköğretimde Web’e Dayalı ve Yüz Yüze Ders Alan Öğrencilerin Öğrenme Stratejilerinin, Bilgisayar Kaygılarının ve Başarı Durumlarının Karşılaştırılması. Doktora Tezi. Eskişehir: Anadolu Üniversitesi.

İSMMAN, A. (2011). Uzaktan Eğitim. Ankara : Pegem Akademi Yayıncılık.

KORESDOSKI A.E. (2000). The value of distance lerarning graduate degree prorams to employer and employees. Unpublished PDH Thesis. Nova Southeastern University.

KÖR, H. (2013). Uzaktan ve Örgün Eğitimin Öğrenci Başarısı Üzerine Etkisinin Araştırılmas1, Gaziantep Ünversitesi Sosyal Bilimler Dergisi, Gaziantep University Journal of Social Sciences, 2013 12(2) Technology Special Issue:267-279

O'NEIL, H. F. (Ed.). (2005). What works in distance learning: Guidelines. Greenwich, CT: Information Age.

O'NEIL, H. F. (Ed.). (2008). What works in distance learning: Sample lessons based on guidelines. Charlotte, NC: Information Age.

PACHNOWSKI, L. M. and Jurczyk, J. P. (2000, February). Correlating self-directed learning with distance learning success. Paper presented at the annual meeting of the Eastern Educational Research Association, Clearwater, FL. ERIC Document No. 441000.

REISER, R. A., \& Dempsey, J. V. (Eds.). (2012). Trends and issues in instructional design and technology (3rd ed. Upper Saddle River, NJ: Erlbaum.

SCHEFFE, H. (1953). A method of judging all contrasts in the analysis of variance. Biometrika, 40, 87-104.

SCHEFFE, H. (1959). The analysis of variance. New York: John Wiley press.

SCHUTTE, J.G. (1997). Virtual teaching in higher education: The new intellectual superhighway or just another traffic jam? California State University Northridge Department of Sociology Retrieved from http://www.csun.edu/sociology/ virexp. Htm

SOEFIJANTO, T. (2002). An effort to implement the adventages of face to learning in distance education. Boston: Boston University.

SOUDER, W.E. (1994). The effectiveness of traditional versus satellite delivery in three management of technology master's degree programs. The American Journal of Distance Education, 7(1), 37-53 
TUKEY, J. W. (1949). Comparing individual means in the analyses of variance. Biometrics, 5, 99-114. 